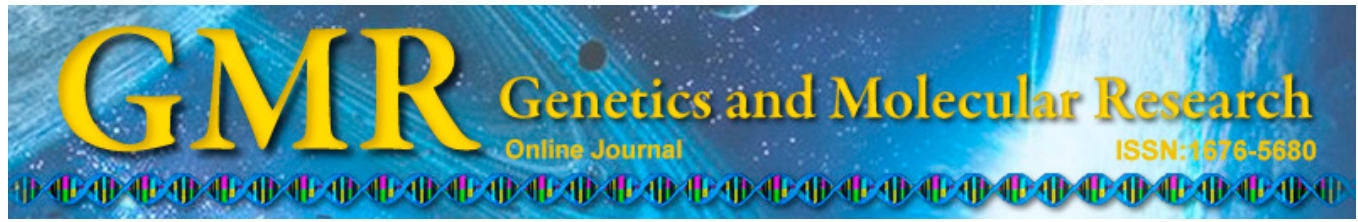

\title{
Correlation analysis of the PNPLA 7 gene polymorphism and susceptibility to menstrual disorder
}

\author{
Y. Su, G.L. Kong, Y.L. Su, Y. Zhou, L.F. Lv, Q. Wang, B.P. Huang, \\ R.Z. Zheng, Q.Z. Li, H.J. Yuan and Z.G. Zhao \\ Department of Endocrinology, \\ The People's Hospital (Henan Provincial People's Hospital), \\ Zhengzhou University, Zhengzhou, China \\ Corresponding author: L.F. Lv \\ E-mail: yongsudoc@163.com
}

Genet. Mol. Res. 14 (1): 1733-1740 (2015)

Received February 10, 2014

Accepted August 27, 2014

Published March 6, 2015

DOI http://dx.doi.org/10.4238/2015.March.6.20

\begin{abstract}
We examined the correlation between PNPLA7 gene polymorphisms at the rs61754920 and rs11137410 loci and menstrual disorder in women of reproductive age in the Central Plain. Genomic DNA was extracted from peripheral blood; polymerase chain reactionligase detection reaction and $\mathrm{SNaPshot}$ genotyping were used to detect polymorphisms in the rs61754920 and rs11137410 gene loci, respectively. The results for the 2 loci in individuals of different blood types were statistically analyzed. The proportion of the AA homozygote at the rs61754920 locus in the PNPLA7 gene was the lowest, while the proportion of the CC homozygote at the rs 11137410 locus in the PNPLA7 gene was the highest. There were no statistical differences in the frequency distribution of genotypes and alleles at the 2 loci between control and test groups. The frequency of the TT genotype at the rs 11137410 locus in women with type O blood was significantly lower in the test group than in the control group. Frequencies of the $\mathrm{C}$ and $\mathrm{T}$ alleles were significantly different between the 2 groups. There
\end{abstract}


may be an association between the PNPLA7 gene and type $\mathrm{O}$ blood or a combined effect of the 2 genes.

Key words: Gene polymorphism; Menstrual disorder; PNPLA7 gene; Susceptibility; Type O blood

\section{INTRODUCTION}

Menstruation is the periodic discharge of the endometrium and blood from the uterus after periodic ovulation. Regular menstruation is considered to be a sign of mature reproductive function. However, menstrual disorder is a common disease in females, which may influence their quality of life (Williams and Creighton, 2012). A cross-sectional survey in Australia showed that approximately $25 \%$ of adolescent females suffered from menstrual disorder (Parker et al., 2010), while another survey performed in 7 colleges by Qiao et al. (2012) revealed that the incidence of premenstrual syndrome was $21.1 \%$ in women of reproductive age. There have been few studies examining the mechanisms of menstrual disorder. However, with the advancement of molecular biological techniques, this disorder can now be examined at a genetic level.

Previous studies have demonstrated that single nucleotidepolymorphisms (SNPs) are closely correlated with various menstrual disorders (Lussiana et al., 2008; Taylor et al., 2010; Biggs and Demuth, 2011; Chen et al., 2011; Dvornyk and Waqar-ul-Haq, 2012; Matsuzaka et al., 2012; He and Murabito, 2014). The PNPLA7 gene on chromosome 9 is primarily expressed in lipid and muscle as an insulin-regulated lysophospholipase, which is important for energy metabolism (Kienesberger et al., 2008) and the maintenance of axonal integrity (Kienesberger et al., 2009). Another study showed that nutritional status strongly influences menstruation (Algars et al., 2014) and that insulin resistance is a main cause of polycystic ovarian syndrome, which is generally complicated by menstrual disorder (Dewailly et al., 2011). Regular menstruation is regulated via the neuroendocrine hypothalamic-pituitary-ovary axis. Therefore, it has been hypothesized that menstrual disorder results from uncontrolled energy metabolism in the hypothalamus or changes in insulin secretion through mutations in the PNPLA7 gene.

We explored SNPs in the PNPLA7 gene on chromosome 9 and investigated their correlation with the susceptibility to menstrual disorder.

\section{MATERIAL AND METHODS}

\section{Subjects}

A total of 1035 unmarried Han women of reproductive age were randomly recruited from various People's Hospitals in Henan, including 337 women with regular menstruation in the control group (32.6\%) and 698 women with irregular menstruation in the test group (67.4\%); 250 subjects were randomly selected for each group. This study was conducted in accordance with the Declaration of Helsinki and with approval from the Ethics Committee of Henan Provincial People's Hospital. Written informed consent was obtained from all participants. 


\section{Criteria}

For menstrual cycle, polymenorrhea was defined as cycles with intervals of 21 or fewer days; oligomenorrhea was defined as periods with intervals of more than 35 days.

For menstrual blood volume, hypomenorrhea was defined as the use of fewer than 2 sanitary pads saturated with menstrual blood per day, while hypermenorrhea was defined as the use of more than 5 sanitary pads saturated with menstrual blood per day during the menstrual period.

For menstrual period, an abnormal period was considered to be more than 7 days or fewer than 3 days.

Dysmenorrhea was defined as ache and pressure in the abdomen or pain in the lower back before, after, or during menstruation that interferes with daily activities.

Regular menstruation was therefore characterized by a normal menstrual cycle, blood volume, and period without dysmenorrheal; otherwise, it was considered to be menstrual disorder (Montoya et al., 2012).

\section{Sample collection}

A uniform questionnaire, physical exams, and diagnostic criteria were applied. The questionnaire was used to determine general conditions, menstrual characteristics, and related familial history, and was conducted by a qualified specialist. The slide method was used to test the blood types of subjects by medical staff from Henan Provincial People's Hospital. Blood $(2 \mathrm{~mL})$ was taken from the cubital vein, collected in 2-mL disposable Venous Blood Collection Tubes containing EDTA-K2, mixed, and stored at $-80^{\circ} \mathrm{C}$ until DNA extraction. Anti-A and anti-B antibodies were purchased from the Biomedical Engineering Center at Hebei Medical University, Shijiazhuang City, China.

\section{DNA extraction}

A whole Blood Genomic DNA Extraction Kit was used according to the protocol, and the DNA was then stored at $-20^{\circ} \mathrm{C}$. The kit was acquired from Shanghai Fenglai Biological Technology Co., Ltd. (Shanghai, China).

\section{Detection of polymorphism}

For the rs61754920 gene locus, the polymerase chain reaction (PCR) forward primer was 5'-GGCAGCATGGATGCGGAGG-3' and the reverse primer was 5'-CGAAGGGTAGGG TTGGAGGGA-3'. PCR primers and probes were designed and synthesized by Shanghai Jierui Company (Shanghai, China). The PCR amplification mixture included $1 \mu \mathrm{L}$ sample DNA, $1.5 \mu \mathrm{L} 10 \mathrm{X}$ buffer, $1.5 \mu \mathrm{L} \mathrm{MgCl}_{2}(25 \mathrm{mM}), 0.3 \mu \mathrm{L}$ dNTPs $(10 \mathrm{mM}), 0.25 \mu \mathrm{L}$ forward and reverse primers $(10 \mu \mathrm{M}), 0.2 \mu \mathrm{L}$ Taq polymerase $(5 \mathrm{U} / \mu \mathrm{L})$, and water to a final volume of 15 $\mu \mathrm{L}$. The PCR protocol included the following steps: initial denaturation at $94^{\circ} \mathrm{C}$ for $2 \mathrm{~min} ; 35$ cycles of denaturation at $94^{\circ} \mathrm{C}$ for $20 \mathrm{~s}$, annealing at $56^{\circ} \mathrm{C}$ for $20 \mathrm{~s}$, and extension at $72^{\circ} \mathrm{C}$ for $40 \mathrm{~s}$; with a final extension at $72^{\circ} \mathrm{C}$ for $3 \mathrm{~min}$. The amplified PCR product was $226 \mathrm{bp}$. The following probe sequences were used: TA, CTCCACCCAGTCCAGGGCAAAGTCA; TG, TTTCTCCACCCAGTCCAGGGCAAAGTCG; TR, -P-ATTTGCCGCACGAAGGACGAC ATCC-FAM-. TA and TG represent 2 left probes with different sequences; TR represents the 
shared right probe with a fluorescent tag. For ligation, $2 \mu \mathrm{L}$ PCR products, $1 \mu \mathrm{L} 10 \mathrm{X}$ Taq DNA ligase buffer, $0.125 \mu \mathrm{L} \mathrm{10X} \mathrm{Taq} \mathrm{DNA} \mathrm{ligase,} 0.01 \mu \mathrm{L}$ probe $(10 \mu \mathrm{M})$, and water to a final volume of $15 \mu \mathrm{L}$ was used. Ligation conditions included 30 cycles at $94^{\circ} \mathrm{C}$ for $30 \mathrm{~s}$ and $56^{\circ} \mathrm{C}$ for $3 \mathrm{~min}$. Next, $1 \mu \mathrm{L}$ ligation products and $10 \mu \mathrm{L}$ loading buffer (mixed with MarK) were denatured at $95^{\circ} \mathrm{C}$ for $3 \mathrm{~min}$, followed by immediate incubation in an ice-water bath. Finally, the sequence was detected in an ABI 3730XL sequencer (Applied Biosystems, Foster City, CA, USA). For the rs61754920 gene locus, the PCR forward primer 5'-TGGACATTGC CCTCCTTGGT-3' and reverse primer 5'-TTGTGTCCCAGGAGAGCCAGG-3' were used (PCR primers and adjacent SNP extension primers were designed and synthesized by Shanghai Jierui). The PCR amplification system included $1 \mu \mathrm{L}$ sample DNA, $1.5 \mu \mathrm{L} 10 \mathrm{X}$ buffer, $1.5 \mu \mathrm{L}$ $\mathrm{MgCl}_{2}(25 \mathrm{mM}), 0.3 \mu \mathrm{L}$ dNTPs $(10 \mathrm{mM}), 0.15 \mu \mathrm{L}$ forward and reverse primers $(10 \mathrm{mM})$, $0.3 \mu \mathrm{L} \mathrm{Taq}$ polymerase $(5 \mathrm{U} / \mu \mathrm{L})$, and water to a final volume of $15 \mu \mathrm{L}$. The PCR protocol included initial denaturation at $95^{\circ} \mathrm{C}$ for $3 \mathrm{~min} ; 11$ cycles of denaturation at $94^{\circ} \mathrm{C}$ for $15 \mathrm{~s}$, annealing at $60^{\circ} \mathrm{C}$ for $15 \mathrm{~s}$, and extension at $72^{\circ} \mathrm{C}$ for $30 \mathrm{~s}$ (decrease of $0.5^{\circ} \mathrm{C}$ after each cycle); 24 cycles of denaturation at $94^{\circ} \mathrm{C}$ for $15 \mathrm{~s}$, annealing at $54^{\circ} \mathrm{C}$ for $15 \mathrm{~s}$, and extension at $72^{\circ} \mathrm{C}$ for $30 \mathrm{~s}$; with a final extension at $72^{\circ} \mathrm{C}$ for $3 \mathrm{~min}$. The amplified PCR product was $172 \mathrm{bp}$. For purification, $3 \mu \mathrm{L}$ PCR product was mixed with $0.8 \mu \mathrm{L}$ FastAP and $0.2 \mu \mathrm{L}$ Exol, followed by incubation at $37^{\circ} \mathrm{C}$ for $15 \mathrm{~min}$ and inactivation of enzyme activity at $80^{\circ} \mathrm{C}$ for $15 \mathrm{~min}$. Exol and FastAP removed the residual primers and dNTPs, respectively. For single-nucleotide primer extension, the forward extension primer was 5'-GAGCCGCGGTGGCTTTTTAA GC-3' and the SNaPshot Kit was used for the extension reaction, which included $1 \mu \mathrm{L}$ SNaPshot reagent, $2 \mu \mathrm{L}$ SNaPshot primers $(0.4 \mu \mathrm{M})$, and $2 \mu \mathrm{L}$ purified PCR products, and water was added to a final volume of $6 \mu \mathrm{L}$. Reaction conditions were $96^{\circ} \mathrm{C}$ for $1 \mathrm{~min} ; 30$ cycles at $96^{\circ} \mathrm{C}$ for $10 \mathrm{~s}, 52^{\circ} \mathrm{C}$ for $5 \mathrm{~s}$, and $60^{\circ} \mathrm{C}$ for $30 \mathrm{~s}$. Next, $1 \mu \mathrm{L}$ extension products mixed with $8 \mu \mathrm{L}$ loading buffer (mixed with MarK) were denatured at $95^{\circ} \mathrm{C}$ for $3 \mathrm{~min}$, followed by immediate incubation in an ice-water bath. The sequence was determined using the $\mathrm{ABI} 3730 \mathrm{XL}$ sequencer.

\section{Statistical analysis}

Hardy-Weinberg equilibrium was tested to determine the genotype distribution in the control group. Differences in the distribution of genotype and allelic frequencies between the 2 groups were analyzed using the chi-square test. Data were analyzed using SPSS v. 17.0 (SPSS, Inc., Chicago, IL, USA). P $<0.05$ was considered to be statistically significant.

\section{RESULTS}

\section{Frequency of blood types (ABO)}

Among all subjects, the frequency of type A blood was the highest (161 cases, 32.2\%) and the frequency of type $\mathrm{AB}$ blood was the lowest (59 cases, 11.8\%). Among women with menstrual disorders, the frequency of type O blood was the highest (69\%) (Table 1). 
Table 1. Investigation of menstrual status in women with different blood types.

\begin{tabular}{lcc}
\hline Blood type & Menstrual disorder (\%) & Normal menstruation (\%) \\
\hline A & $75(46.6)$ & $86(53.4)$ \\
B & $61(40.4)$ & $90(59.6)$ \\
AB & $25(42.4)$ & $34(57.6)$ \\
O & $89(69.0)$ & $40(31.0)$ \\
\hline
\end{tabular}

\section{Hardy-Weinberg equilibrium}

In the test group, the genotype distributions at the 2 loci were consistent with HardyWeinberg equilibrium (rs61754920, $\chi^{2}=0.23, \mathrm{P}>0.05$; rs11137410, $\chi^{2}=4.65, \mathrm{P}>0.05$ ), which indicated that the sample accurately represented the population.

\section{Correlation between allele or genotype and susceptibility to menstrual disorder}

In the test group, the frequencies of the GG, GA, and AA genotypes at the rs 61754920 locus in the PNPLA7 gene were $60,35.6$, and $4.4 \%$, respectively, while the proportion of the AA homozygote was the lowest and the frequencies of the A and G alleles were 22.2 and $77.8 \%$, respectively; the proportion of CC homozygotes at the rs 11137410 locus was the highest (63.2\%), followed by heterozygotes $(32.4 \%)$, while the frequencies of the $\mathrm{T}$ and $\mathrm{G}$ alleles were 20.6 and $79.4 \%$, respectively. There were no statistical differences in the frequency distribution of genotypes and alleles at the 2 loci between the control and test groups (Table 2).

\begin{tabular}{|c|c|c|c|c|c|c|c|c|c|}
\hline \multirow[t]{2}{*}{ SNPs } & \multirow[t]{2}{*}{ Genotype/allele } & \multicolumn{2}{|c|}{ Test group } & \multicolumn{2}{|c|}{ Control group } & \multirow[t]{2}{*}{$\chi^{2}$} & \multirow[t]{2}{*}{$P$} & \multirow[t]{2}{*}{ Odds ratio } & \multirow{2}{*}{$\begin{array}{c}95 \% \text { confidence } \\
\text { interval }\end{array}$} \\
\hline & & Cases (N) & Frequency $(\%)$ & Cases (N) & Frequency (\%) & & & & \\
\hline \multirow[t]{5}{*}{ s61754920 } & GG & 150 & 0.600 & 149 & 0.596 & 2.939 & 0.230 & & \\
\hline & GA & 89 & 0.356 & 80 & 0.320 & & & & \\
\hline & AA & 11 & 0.044 & 21 & 0.084 & & & & \\
\hline & A & 111 & 0.222 & 122 & 0.244 & & & & \\
\hline & G & 389 & 0.778 & 378 & 0.756 & 0.677 & 0.411 & 1.131 & $(0.843-1.517)$ \\
\hline \multirow[t]{5}{*}{ s11137410 } & $\mathrm{CC}$ & 158 & 0.632 & 155 & 0.620 & 2.321 & 0.313 & & \\
\hline & $\mathrm{CT}$ & 81 & 0.324 & 76 & 0.304 & & & & \\
\hline & TT & 11 & 0.044 & 19 & 0.076 & & & & \\
\hline & $\mathrm{T}$ & 103 & 0.206 & 114 & 0.228 & & & & \\
\hline & $\mathrm{C}$ & 397 & 0.794 & 386 & 0.772 & 0.712 & 0.399 & 1.138 & $(0.842-1.538)$ \\
\hline
\end{tabular}

\section{Correlation between polymorphisms and susceptibility to menstrual disorder}

As shown in Table 3, there were significant differences in the distribution of genotype and allele frequencies at the rs11137410 locus in subjects with type O blood between the control and test groups. The frequency of the TT genotype at the rs 11137410 locus in women with type $\mathrm{O}$ blood was significantly lower in the test group than that in the control group ( $\mathrm{P}$ $=0.005)$. The frequencies of the $\mathrm{C}$ and $\mathrm{T}$ alleles were significantly different between the 2 groups $(\mathrm{P}=0.027)$. 
Table 3. Genotype and allele frequency distributions at locus rs 11137410 in women with type O blood.

\begin{tabular}{lcccc}
\hline Genotype & Control group [N (\%)] & Test group [N (\%)] & P value & Odds ratio (95\% confidence interval) \\
\hline CC & $21(52.5)$ & $61(68.5)$ & & \\
CT & $16(40.0)$ & $28(31.5)$ & 0.206 & $0.602(0.274-1.327)$ \\
TT & $3(7.5)$ & $0(0.0)$ & $0.005^{*}$ & $0.050(0.002-1.007)$ \\
Allele & $58(72.5)$ & $150(84.3)$ & & \\
C & $22(27.5)$ & $28(15.7)$ & $0.027^{*}$ & $0.492(0.261-0.926)$ \\
T & & &
\end{tabular}

$* \mathrm{P}<0.05$ was considered statistically significant.

\section{DISCUSSION}

Menstruation and its regulation is a complex process, which involves the neuroendocrine hypothalamic-pituitary-ovary axis and may correlate with heredity, race, and age. Menstrual disorders are disruptive physical and emotional symptoms just before and during menstruation, including abnormal blood volume, irregular cycles, anxiety, irritability, and abdominal pain.

Previous studies have demonstrated that SNPs are closely correlated with various menstrual disorders; for example, Dvornyk and Waqar-ul-Haq (2012) and He and Murabito (2014) identified a susceptibility gene associated with age at menarche. Taylor et al. (2010) found that polymorphisms in the progesterone receptor gene are related to early age at menarche and a short menstrual cycle by analyzing the progesterone receptor gene and SNPs at 37 loci upstream and downstream of the gene. Chen et al. (2011) identified a susceptibility gene for polycystic ovarian syndrome located at the 9q33.3 locus through a genome-wide association study. It has been reported that polymorphism of the cytochrome P450 gene is correlated with endometriosis (Matsuzaka et al., 2012), and the incidence of premenstrual syndrome in identical twins was found to be much higher than that in fraternal twins (Biggs and Demuth, 2011). Mutations in the follicle-stimulating hormone receptor may induce amenorrhea, infertility, and premature ovarian failure (Lussiana et al., 2008). These results indicate that genetic susceptibility is a very important factor in menstrual disorder.

The human genome expresses 9 patatin-like phospholipase domain-containing proteins (PNPLA1-9), and polymorphisms in these genes have been shown to be important in diseases related to the regulation of energy balance and neuron stability, as well as age-related bone disease (Kienesberger et al., 2009). It has been reported that a polymorphism at locus rs738409 in the PNPLA3 gene (encoding 1148M) was closely correlated with increases in liver lipid content and serum alanine aminotransferase level (Chen et al., 2010; Romeo et al., 2010). Menstrual disorder has been confirmed to be associated with body weight (Ornstein et al., 2011). Therefore, the PNPLA gene family may be correlated with menstruation.

The PNPLA7 gene on chromosome 9 is mainly expressed in lipid and muscle as an insulin-regulated lysophospholipase, which is important for maintaining axonal integrity (Kienesberger et al., 2009). The PNPLA7 gene plays important role in energy metabolism (Kienesberger et al., 2008); its expression is up-regulated by fasting and adipocyte differentiation and is down-regulated by insulin. A recent study showed that nutritional status greatly influences menstruation (Algars et al., 2014) and that insulin resistance is the primary cause of polycystic ovarian syndrome. Regular menstruation is regulated via the neuroendocrine hypothalamic-pituitary-ovary axis. Therefore, menstrual disorder may result from uncontrolled energy metabolism in the hypothalamus or changes in insulin secretion through mutations in the PNPLA7 gene. 
In this study, we analyzed the correlation between genetic polymorphisms and menstrual disorders in 500 women of reproductive age in the Central Plains and found no statistical differences in the frequency distribution of genotypes and alleles at the rs61754920 and rs11137410 loci between control and test groups. The frequency of the TT genotype at locus rs11137410 in women with type O blood was significantly lower in the test group than in the control group $(\mathrm{P}=0.005)$, indicating that the $\mathrm{T}$ mutation is a protective factor for menstrual disorders. Differences in the distribution of genotypes and alleles in the PNPLA7 gene before and after stratification of the ABO blood groups were observed, which may be correlated with blood type. This indicates that menstrual disorders are related to blood type, which is consistent with results presented in the literature.

At the American Society for Reproductive Medicine Annual Meeting of 2010 in Denver, CO, USA, experts proposed that type O blood is associated with infertility, suggesting that blood type is correlated with menstrual disorder (Sharma et al., 2008). Type ABO blood genes are located on chromosome 9q34.1-9q34.2 (Pelzer et al., 2013), while the PNPLA7 gene is located on chromosome 9q34.3 (Baulande and Langlois, 2010); thus, there may be a relationship between the PNPLA7 gene and type O blood, which would explain the observed differences in the distribution of genotypes and alleles at this locus in type $\mathrm{O}$ blood between the control and test groups. Recent studies examining the correlation between gene polymorphism and disease susceptibility have focused on the combined effects of multiple genes. However, menstrual disorder likely results from the interaction between PNPLA7 and type ABO genes, and the mechanism requires further investigation.

\section{REFERENCES}

Algars M, Huang L, Von Holle AF, Peat CM, et al. (2014). Binge eating and menstrual dysfunction. J. Psychosom. Res. 76: $19-22$.

Baulande S and Langlois C (2010). Proteins sharing PNPLA domain, a new family of enzymes regulating lipid metabolism. Med. Sci. 26: 177-184.

Biggs WS and Demuth RH (2011). Premenstrual syndrome and premenstrual dysphoric disorder. Am. Fam. Physician 84: 918-924.

Chen W, Chang B, Li L and Chan L (2010). Patatin-like phospholipase domain-containing 3/adiponutrin deficiency in mice is not associated with fatty liver disease. Hepatology 52: 1134-1142.

Chen ZJ, Zhao H, He L, Shi YH, et al. (2011). Genome-wide association study identifies susceptibility loci for polycystic ovary syndrome on chromosome 2p16.3, 2p21 and 9q33.3. Nat. Genet. 43: 55-59.

Dewailly D, Gronier H, Poncelet E, Robin G, et al. (2011). Diagnosis of polycystic ovary syndrome (PCOS): revisiting the threshold values of follicle count on ultrasound and of the serum AMH level for the definition of polycystic ovaries. Hum. Reprod. 26: 3123-3129.

Dvornyk V and Waqar-ul-Haq (2012). Genetics of age at menarche: a systematic review. Hum. Reprod. Update 18: 198-210.

$\mathrm{He} \mathrm{C}$ and Murabito JM (2014). Genome-wide association studies of age at menarche and age at natural menopause. Mol. Cell. Endocrinol. 382: 767-779.

Kienesberger PC, Lass A, Preiss-Land K, Wolinski H, et al. (2008). Identification of an insulin-regulated lysophospholipase with homology to neuropathy target esterase. J. Biol. Chem. 283: 5908-5917.

Kienesberger PC, Oberer M, Lass A and Zechner R (2009). Mammalian patatin domain containing proteins: a family with diverse lipolytic activities involved in multiple biological functions. J. Lipid Res. 50: 63-68.

Lussiana C, Guani B, Mari C, Restagno G, et al. (2008). Mutations and polymorphisms of the FSH receptor (FSHR) gene: clinical implications in female fecundity and molecular biology of FSHR protein and gene. Obstet. Gynecol. Surv. 63: 785-795.

Matsuzaka Y, Kikuti YY, Goya K, Suzuki T, et al. (2012). Lack of an association human dioxin detoxification gene polymorphisms with endometriosis in Japanese women: results of a pilot study. Environ. Health Prev. Med. 17: $512-517$. 
Montoya JS, Cabezza AH, Rojas OM, Navarrete RC, et al. (2012). Menstrual disorders in adolescents. Bol. Med. Hosp. Infant. Mex. 69: 60-72.

Ornstein RM, Copperman NM and Jacobson MS (2011). Effect of weight loss on menstrual function in adolescents with polycystic ovary syndrome. J. Pediatr. Adolesc. Gynecol. 24: 161-165.

Parker M, Sneddon A and Arbon P (2010). The menstrual disorder of teenagers (MDOT) study: determining typical menstrual patterns and menstrual disturbance in a large population-based study of Australian teenagers. BJOG 117: 185-192.

Pelzer U, Klein F, Bahra M, Sinn M, et al. (2013). Blood group determinates incidence for pancreatic cancer in Germany. Front. Physiol. 24: 118.

Qiao M, Zhang H, Liu H, Luo S, et al. (2012). Prevalence of premenstrual syndrome and premenstrual dysphoric disorder in a population-based sample in China. Eur. J. Obstet. Gynecol. Reprod. Biol. 162: 83-86.

Romeo S, Huang-Doran I, Baronig G and Kotronen A (2010). Unravelling the pathogenesis of fatty liver disease: patatinlike phospholipase domain-containing 3 protein. Curr. Opin. Lipidol. 21: 247-252.

Sharma A, Taneja DK, Sharma P and Saha R (2008). Problems related to menstruation and their effect on daily routine of students of a medical college in Delhi, India. Asia Pac. J. Public Health 20: 234-241.

Taylor KC, Small CM, Epstein MP, Sherman SL, et al. (2010). Associations of progesterone receptor polymorphisms with age at menarche and menstrual cycle length. Horm. Res. Paediatr. 74: 421-427.

Williams CE and Creighton SM (2012). Menstrual disorders in adolescents: review of current practice. Horm. Res. Paediatr. 78: 135-143. 